Int. J. Environ. Res. Public Health 2007, 4(3), 203-210

International Journal of

Environmental Research and Public Health

ISSN 1661-7827

www.ijerph.org

(C) 2007 by MDPI

\title{
Mathematical Models of Cobalt and Iron Ions Catalyzed Microwave Bacterial Deactivation
}

\author{
Earl Benjamin III ${ }^{1}$, Aron Reznik ${ }^{2}$, Ellis Benjamin ${ }^{1}$ and Arthur L. Williams ${ }^{3 *}$ \\ ${ }^{1}$ Arkansas State University, College of Sciences and Mathematics, Department of Chemistry and Physics, PO Box 419, State \\ University, AR 72467, USA \\ ${ }^{2}$ Morgan State University, School of Computer, Mathematical, and Natural Sciences, Mathematics Department, 1700 East Cold \\ Spring Lane, Baltimore MD 21251, USA \\ ${ }^{3}$ Morgan State University, School of Computer, Mathematical, and Natural Sciences, Biology Department, 1700 East Cold \\ Spring Lane, Baltimore MD 21251, USA \\ *Correspondence to Dr. Arthur L. Williams; E-mail: awillia5@morgan.edu
}

Received: 19 June 2007 / Accepted: 29 August 2007 / Published: 30 September 2007

\begin{abstract}
Time differences for Enterococcus faecalis, Staphylococcus aureus, and Escherichia coli survival during microwave irradiation (power $130 \mathrm{~W}$ ) in the presence of aqueous cobalt and iron ions were investigated. Measured dependencies had "bell" shape forms with maximum bacterial viability between $1-2$ min becoming insignificant at 3 minutes. The deactivation time for E. faecalis, S. aureus and E.coli in the presence of metal ions were smaller compared to a water control (4 $-5 \mathrm{~min})$. Although various sensitivities to the metal ions were observed, S. aureus and E. coli and were the most sensitive for cobalt and iron, respectively. The rapid reduction of viable bacteria during microwave treatment in the presence of metal ions could be explained by increased metal ion penetration into bacteria. Additionally, microwave irradiation may have increased the kinetic energy of the metal ions resulting in lower survival rates. The proposed mathematical model for microwave heating took into account the "growth" and "death" factors of the bacteria, forming second degree polynomial functions. Good relationships were found between the proposed mathematical models and the experimental data for bacterial deactivation (coefficient of correlation $0.91-0.99$ ).
\end{abstract}

Keywords: Bacteria, iron, cobalt, theoretical model, microwave

\section{Introduction}

Effective water disinfection from fecal coliforms is a problem whose solution, leads to the improvement of environmental health conditions. A resolution to this problem can reduce the levels of morbidity and mortality worldwide [1]. Presently, water disinfection of fecal coliforms commonly uses chemical and conventional radiant heating methods. Chemical methods use disinfecting compounds, such as hypochlorite, to disrupt normal cellular function [2] . Bacterial deactivation by conventional radiant heating is achieved through the thermal decay of biomolecules including proteins and DNA [3]. Both of these methods maintain fundamental disadvantages including harmful side effects and extensive disinfecting time.
To address this problem, the identification of rapid disinfection methods such as microwave heating was explored. Microwave heating is the use of microwave radiation $(2.45 \mathrm{GHz})$ to induce collisional deactivation resulting in thermal heating [4]. This process maintains several advantages over conventional radiant heating for bacterial deactivation including rapid heating rates and reduced energy requirements [5]. Additionally, microwave heating has been found to heat more uniformly compared to conventional radiant heating thereby increasing energy efficiency [6].

Bacterial deactivation using microwave irradiation showed both thermal and non-thermal effects. Goldblith and Wang [7] compared the deactivation of Escherichia coli and Bacillus subtilis spores using microwave irradiation versus conventional radiant heating. They 
suggested that the deactivation of these bacteria resulted from the dielectric heating and did not maintain any secondary effect from the microwave irradiation. Jeng et al. [8] found no difference between conventional radiant and microwave heating for the disinfection of $B$. subtilis spores in automated temperature monitoring systems. Kazbekov and Vyacheslavov [9] found a series of biochemical processes that were altered in E. coli and $B$. subtilis under microwave irradiation which included thymidine and thymine uptake, leakage of potassium and hydrogen ions, and uptake of DNA. Fujikawa et al. [10] found no major differences in deactivation rates of $E$. coli in phosphate buffer between microwave and conventional radiant heating. Welt et al. [11] also found no difference between conventional and microwave deactivation of Clostridium sporogenes at $90^{\circ} \mathrm{C}, 100^{\circ} \mathrm{C}$, and $110^{\circ} \mathrm{C}$. Lechowich et al. [12], Vela et al. [13], Rosén [14] also found that the deactivation of several bacteria, including Streptococcus faecalis (later classified as Enterococcus faecalis) and Saccharomyces cerevisiae, under microwave irradiation resulted from the dielectric heating.

Conversely, Shin and Pyun [15] compared the results of deactivation of Lactobacillus plantarum by conventional heating at $50^{\circ} \mathrm{C}$ versus continuous microwave heating and pulsed higher power microwave heating over a 30 minute period. They found greater reduction in bacterial survival for pulsed microwave heating relative to conventional and continuous microwave heating. These results suggested a secondary non-thermal mechanism assisted the deactivation of these bacteria during microwave irradiation. Culkin and Fung [16] and Kozempel et al. [17] also suggest that a secondary non-thermal mechanism assisted in the deactivation of certain species of bacteria. Heddleson and Doores reported that non-thermal effects are likely to be due to the lack of precise measurements of the timetemperature history and its spatial variations [18].

In our recent paper dependencies between bacterial viability of Enterococcus faecalis, Staphylococcus aureus, and Escherichia coli versus microwave heating time and conventional radiant temperature, were found to have "bell" shape forms [19]. The proposed mathematical models for conventional and microwave heating took into account "growth" and "death" factors of bacteria whose, relationships formed second degree polynomial functions. These models were found to be consistent with experimental data maintaining correlation coefficients between $0.84-0.99$.

Watanabe et al. showed that ionic strength was able to influence the bacterial survival during microwave irradiation [20]. They showed that 10-fold increase in E. coli deactivation rates in the presence of molar concentrations of $\mathrm{NaCl}$ and $\mathrm{KCl}$. Transitional metals ions play an important role in the life processes of bacteria [21]. Several transitional metals, such as calcium, cobalt, copper, chromium, potassium, iron, magnesium, nickel, zinc, manganese, sodium, are essential for normal biochemical processes [22,23]. In small concentrations they serve as micronutrients and are used for redox- processes, stabilize molecules through electrostatic interactions, are components of various enzymes, and regulate osmotic pressure [21]. However, other transitional metals such as silver, aluminum, cadmium, gold, mercury, lead, have no biological role and are potentially toxic to bacteria [24]. Toxicity of transitional metal ions depends on their concentration, form, and other factors, including water temperature [25, 26, 27].

Most scientific investigations with transitional metal ions were conducted with silver and copper ions in combination with other compounds [28, 29, 30]. Butkus et al. and Chambers et. al. reported that the addition of silver ions was effective against coliforms [31,32]. Abad et al. [33] found that the existence of copper and silver ions in combination with low levels of chlorine leads to increased reduction of poliovirus. Landeen et al. showed the efficiency of copper and silver ions in combination with low level of chlorine for deactivation of Legionella pneumophilla [34]. Short et al. [35] established that copper ions reduced the number of Staphylococcus aures. Ragab-Depre [36] found that addition of a hydrogen peroxide-ascorbic acid-Cu(II) (60 $\mathrm{min})$ to secondary effluents resulted in $99 \%$ reduction of Enterobacteriaceal, total and fecal coliforms and Staphylococci. Oganesov [37] proposed a mechanism for the deactivation of bacteria in water using silver ions. Myers and Nealson [38] studied the influence of manganese oxide on bacterial reduction and growth. Nealson and Saffarini [39] used iron and manganese for anaerobic respiration. Calomiris et al. [40] studied the effects of different metal ions such as $\mathrm{Cu}^{2+}, \mathrm{Pb}^{2+}, \mathrm{Zn}^{2+}, \mathrm{Al}^{3+}, \mathrm{Sn}^{2+}$, and $\mathrm{Cd}^{2+}$ on Escherichia coli, Staphylococcus aureus, and several other bacteria. They found that the existence of $\mathrm{Cu}^{2+}$ and $\mathrm{Zn}^{2+}$ sufficiently decreased the number of Escherichia coli in water. Staphylococcus aureus was sensitive to all of the metal ions mentioned above except the ion $\mathrm{Al}^{3+}$. Nakahara et al. [41, 42] described the resistance of staphylococcal strains to several metal ions and antibiotics.

Unfortunately, the process of bacterial deactivation using only transitional metal ions takes several hours. On the other hand, the presence of metal ions can accelerate bacterial deactivation when coupled with other methods. For example, Butkus et al. [32] found that the addition of silver ions enhanced deactivation of coliphage MS-2 by $\mathrm{UV}$ disinfection. It is proposed that the presence of metal ions may increase the deactivation rate of bacteria during microwave treatment, thereby, reducing the time of treatment. In this work the effect of iron and cobalt ions in water on microwave deactivation of E. faecalis, $S$. aureus and E. coli was investigated.

\section{Materials and Methods}

Microwave Deactivation of E. faecalis, S. aureus and E. coli in Distilled Water

Stock cultures of E. faecalis, S. aureus and E. coli (Ward Natural Scientific, Rochester, NY) were created by 
growing them in TSB (Tryptic Soy Broth) overnight in a Labline Imperial III Incubator (model \#305) at a temperature of $37^{\circ} \mathrm{C}$. An aliquot of $10 \mu \mathrm{L}$ of stock culture was then placed into $250 \mathrm{~mL}$ sample vials containing 100 $\mathrm{mL}$ of distilled deionized water purified by a Barnsted ePure System (model \#D4641). The sample vials were then heated in a Panasonic Inverter Microwave (model \#NN-S543BF) at power $130 \mathrm{~W}$ for $1,2,3,4$, and 5 minutes. Results were compared with control samples, which were not microwave irradiated.

Fifty microliters of the test solutions were plated in exponential spiral fashion on to 10 TSA (Tryptic Soy Agar) plates for each sample group using a Spiral Biotech Autoplate 4000 (model \#AP 4000). The plates were then incubated overnight in a Labline Imperial III Incubator (model \#305). Finally, the colony forming units were counted using a Spiral Biotech Q-count (model \#510) auto-plate reader set for a $50 \mu \mathrm{L}$ exponential spiral pate setting. The CFUs (colony forming units) were then calculated and graphed using Grapad Prism ${ }^{\circledR}$.

Microwave Deactivation of E. faecalis, S. aureus and E. coli in the Presence of $1 \mu \mathrm{M}$ Cobalt and Iron Ions

Stock cultures of E. faecalis, S. aureus and E. coli (Ward Natural Scientific, Rochester, NY) were created by growing them in TSB (Tryptic Soy Broth) overnight in a Labline Imperial III Incubator (model \#305) at temperature of $37^{\circ} \mathrm{C}$. An aliquot of $10 \mu \mathrm{L}$ of stock culture was then placed into $250 \mathrm{~mL}$ sample vials containing $100 \mathrm{~mL}$ a $1.0 \mathrm{x}$ $10^{-6} \mathrm{M}$ of Iron or Cobalt ion solution. The sample vials were then microwave heated in a Panasonic Inverter Microwave (model \#NN-S543BF) at power $130 \mathrm{~W}$ for 1, 2, 3,4 , and 5 minutes. Results were compared with control samples, which were not microwave irradiated.

The CFUs of a $50 \mu \mathrm{L}$ aliquot of the test solutions were calculated using the same method previously described for distilled water samples.

\section{Results}

Effect of Existence of Cobalt Ions in Water on Microwave Deactivation of E. faecalis, S. aureus and E. coli

Experimental results for microwave irradiation of $E$. faecalis, S. aureus, and E. coli in the presence of cobalt ions in water are summarized into Table 1 and Figs. $1-3$ (square points). The results showed the existence of two distinct processes: increasing of number of viable bacteria with microwave time of during the first stage of heating, and passing through maximum value of bacterial viability then decreases in relationship to microwave time.

We can take into account two processes as previously described [19]: "growth factor" and "death factor" processes. For E. faecalis the "growth factor" was found in the first minute of microwave heating showing a $2.4 \%$ increase in bacterial viability. Above the optimal microwave time, $E$. faecalis viability decreased. The "death factor" occurred between the first and third minutes showing $102.4 \%$ decrease in bacterial viability. The greatest drop in bacterial viability reduction $(96.6 \%)$ was found between the second and third minutes of microwave heating.

Table 1: Bacterial survival of E. faecalis, S. aureus, and E. coli at various times using microwave heating in the presence and absence of cobalt ions.

\begin{tabular}{|c|c|c|c|c|}
\hline Bacteria & $\begin{array}{l}\text { Time } \\
\text { (min) }\end{array}$ & $\begin{array}{c}\text { Bacteria } \\
\text { survival } \\
\text { without } \\
\text { cobalt } \\
\text { ions, \% } \\
\end{array}$ & $\begin{array}{c}\text { Bacteria } \\
\text { survival } \\
\text { with cobalt } \\
\text { ions, } \\
\% \\
\end{array}$ & $\begin{array}{r}\text { Difference, } \\
\% \\
\end{array}$ \\
\hline \multirow{5}{*}{$\begin{array}{l}\text { E. } \\
\text { faecalis }\end{array}$} & $\begin{array}{l}\text { Control } \\
\text { sample }\end{array}$ & 100 & 100 & 0 \\
\hline & 1 & 120.3 & 102.4 & 17.9 \\
\hline & 2 & 112.0 & 100.4 & 11.6 \\
\hline & 3 & 118.6 & 3.8 & 114.8 \\
\hline & 4 & 32.0 & 0 & 32.0 \\
\hline \multirow{5}{*}{ S. aureus } & $\begin{array}{l}\text { Control } \\
\text { sample }\end{array}$ & 100 & 100 & 0 \\
\hline & 1 & 138.7 & 54.2 & 84.5 \\
\hline & 2 & 94.3 & 65.1 & 29.2 \\
\hline & 3 & 73.2 & 0 & 73.2 \\
\hline & 4 & 0.6 & 0 & 0.6 \\
\hline \multirow{5}{*}{ E. coli } & $\begin{array}{l}\text { Control } \\
\text { sample }\end{array}$ & 100 & 100 & 0 \\
\hline & 1 & 116.7 & 125.0 & -8.3 \\
\hline & 2 & 108.7 & 116.0 & -7.3 \\
\hline & 3 & 24.9 & 0 & 24.9 \\
\hline & 4 & 0.004 & 0 & 0.004 \\
\hline
\end{tabular}

Table 1 shows the bacterial viabilities of $E$. faecalis, $S$. aureus, and E. coli $(\mathrm{n}=10)$ when microwaved for 4 minutes in the presence of cobalt ions compared to control samples (distilled water). The results showed notably lower bacterial viability in the presence of cobalt versus that of the control samples. Maximum differences were found between the first and third minutes of microwave heating.

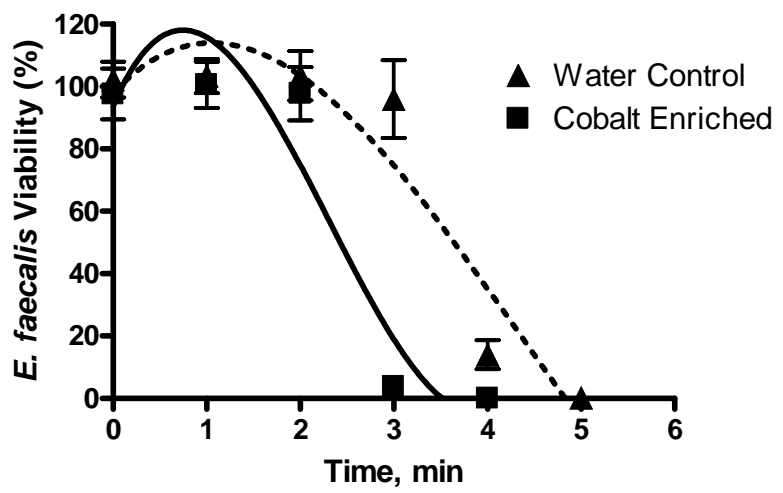

Figure 1: Effect of cobalt ions on microwave disinfection of $E$. faecalis. Shows the effect that cobalt ions (solid line) have on the deactivation of E. faecalis $(\mathrm{n}=10)$ during microwave heating compared to a distilled water control (dotted line). Cobalt ions reduced the time necessary for microwave disinfection of $E$. faecalis. 


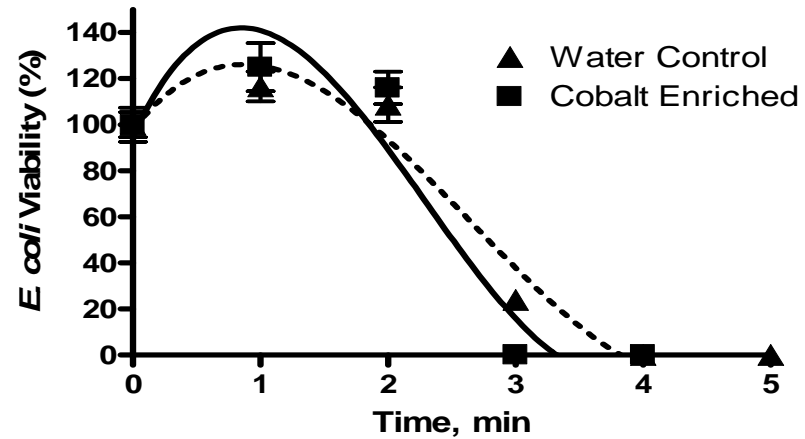

Figure 2: Effect of cobalt ions on microwave disinfection of $E$. coli. Illustrates the effect that cobalt ions (solid line) have on the deactivation of $E$. coli $(\mathrm{n}=10)$ during microwave heating compared to a distilled water control (dotted line). Cobalt ions had negligible effects on the microwave disinfection of E. coli.

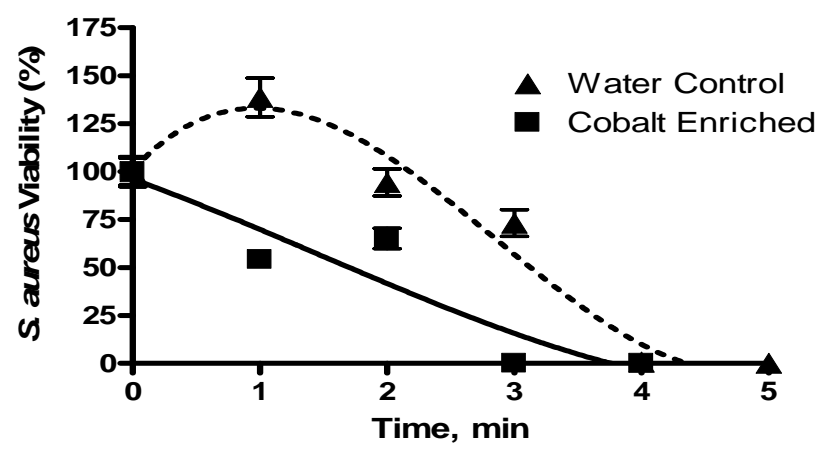

Figure 3: Effect of cobalt ions on microwave disinfection of $S$. aureus. Demonstrates the effect that cobalt ions (solid line) have on the deactivation of $S$. aureus $(\mathrm{n}=10)$ during microwave heating compared to a distilled water control (dotted line). Cobalt ions appeared to enhance microwave radiation's disinfection ability for $S$. aureus.

E. coli also had a "growth factor" in the first minute of microwave irradiation $(25.0 \%$ increase bacterial viability). After passing the maximum value, E. coli viability decreased. The largest drop in E. coli viability $(116 \%)$ was found between the second and third minutes of microwave irradiation.

In contrast with other bacteria, S. aureus showed no major change in bacterial viability in the first minute of the microwave heating. After this initial minute, $S$. aureus viability then slowly decreased in the second minute with a $34.9 \%$ reduction. The third minute showed a $65.1 \%$ decrease in $S$. aureus viability. We can explain this fact by assuming that the "death factor" is influenced by the presence of cobalt ions which had a powerful effect on $S$. aureus compared to other test organism.

For comparison, in Table 1 and Figs. $1-3$ we also show data from our previous paper [19] for microwave treatment for E. faecalis, S. aureus and E. coli in distilled water (triangular points). This data illustrates that the disinfection $\mathrm{s}$ in the presence of cobalt ions $(3 \mathrm{~min})$ is less than that of the distilled water control (4 - $5 \mathrm{~min})$.
Therefore, the presence of cobalt ions into water increased the efficiency of the microwave deactivation of bacteria.

Effect of Existence of Iron Ions in Water on Microwave Deactivation of E. faecalis, S. aureus and E. coli

Experimental results for microwave irradiation of $E$. faecalis, $S$. aureus, and E. coli in the presence of iron ions into water are summarized into Table 2 and Figs. $4-6$ (square points). The results also showed the existence of both "growth" and "death" factors. In this circumstance, the "death" factor for E. faecalis is weaker, and S. aureus and $E$. coli are stronger in comparison with the influence of cobalt ions.

For E. faecalis the "growth factor" was found in the first minute of microwave heating showing a $4.7 \%$ increase in bacterial viability. The "death factor" for E. faecalis occurred between the first and fourth minutes leads to $104.7 \%$ of bacterial viability reduction. The greatest decline in bacterial viability reduction was found between the second and third minutes of microwave irradiation $(63.7 \%)$. However, the influence of iron ions on E. faecalis was weaker when compared with the influence cobalt ions, and at the third minute results $(38.2 \%)$.

Table 2: Bacterial survival of E. faecalis, S. aureus, and $E$. coli at various times using microwave heating in the presence and absence of iron ions.

\begin{tabular}{|c|c|c|c|c|}
\hline Bacteria & $\begin{array}{l}\text { Time } \\
\text { (min) }\end{array}$ & $\begin{array}{c}\text { Bacteria } \\
\text { survival } \\
\text { without } \\
\text { cobalt } \\
\text { ions, \% }\end{array}$ & $\begin{array}{c}\text { Bacteria } \\
\text { survival } \\
\text { with } \\
\text { cobalt } \\
\text { ions, } \\
\%\end{array}$ & $\begin{array}{r}\text { Difference, } \\
\%\end{array}$ \\
\hline \multirow{5}{*}{ E. faecalis } & $\begin{array}{l}\text { Control } \\
\text { sample }\end{array}$ & 100 & 100 & 0 \\
\hline & 1 & 120.3 & 104.7 & 15.6 \\
\hline & 2 & 112.0 & 101.9 & 10.1 \\
\hline & 3 & 118.6 & 38.2 & 80.4 \\
\hline & 4 & 32.0 & 0 & 32.0 \\
\hline \multirow{5}{*}{ S. aureus } & $\begin{array}{l}\text { Control } \\
\text { sample }\end{array}$ & 100 & 100 & 0 \\
\hline & 1 & 138.7 & 98.8 & 39.9 \\
\hline & 2 & 94.3 & 96.3 & -2.0 \\
\hline & 3 & 73.2 & 2.3 & 70.9 \\
\hline & 4 & 0.6 & 0 & 0.6 \\
\hline \multirow{5}{*}{ E. coli } & $\begin{array}{l}\text { Control } \\
\text { sample }\end{array}$ & 100 & 100 & 0 \\
\hline & 1 & 116.7 & 0.3 & 116.4 \\
\hline & 2 & 108.7 & 0 & 108.7 \\
\hline & 3 & 24.9 & 0 & 24.9 \\
\hline & 4 & 0.004 & 0 & 0.004 \\
\hline
\end{tabular}


Table 2 shows the bacterial viabilities of $E$. faecalis, $S$. aureus, and E. coli $(\mathrm{n}=10)$ when micro-waved for 4 minutes in the presence of iron ions compared to control samples (distilled water). The results showed that the presence of iron reduced the disinfection time for all test bacteria. The most significant decrease was $E$ coli whose disinfection time reduced from four minutes to one minute.

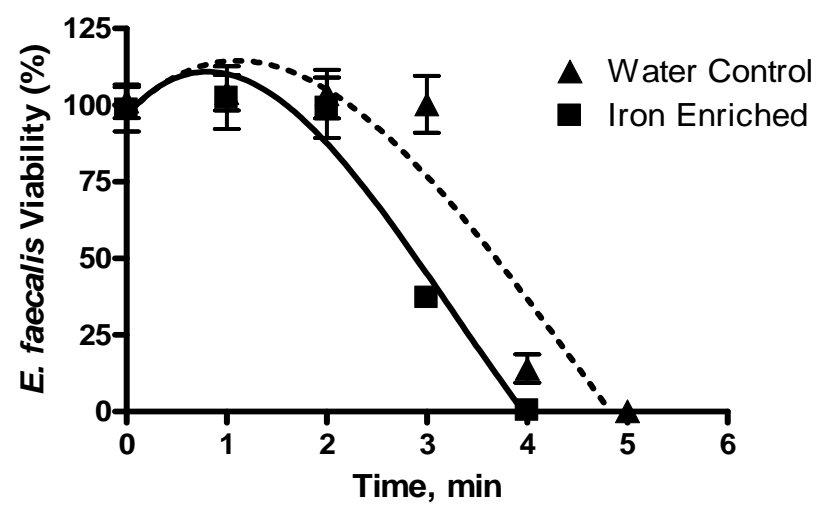

Figure 4: Effect of iron ions on microwave disinfection of E. faecalis. Illustrates the effect that iron ions (solid line) have on the deactivation of E. faecalis $(n=10)$ during microwave heating compared to a distilled water control (dotted line). Iron ions had a trivial effect on microwave disinfection of $E$. faecalis.

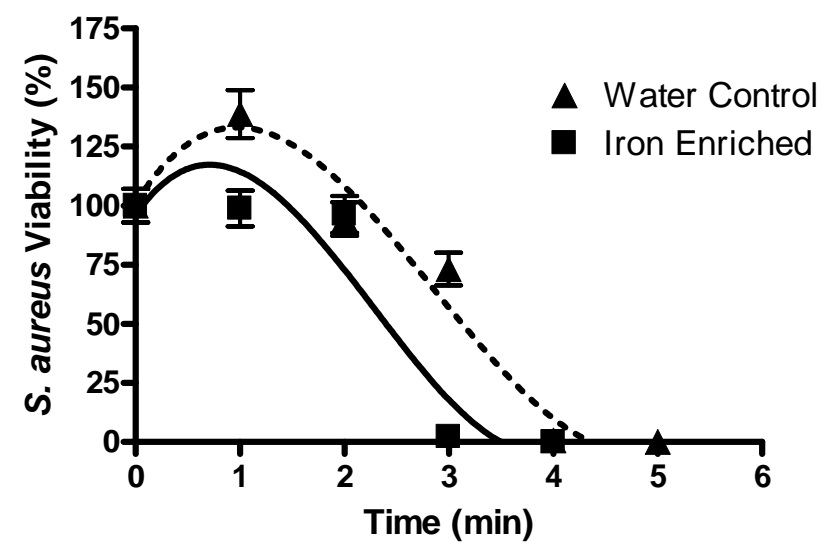

Figure 5: Effect of iron ions on microwave disinfection of $S$. aureus. Illustrates the effect that iron ions (solid line) have on the deactivation of $S$. aureus $(n=10)$ during microwave heating compared to a distilled water control (dotted line). Similar to E. faecalis, iron ions had a negligible effect on microwave disinfection of $S$. aureus.

The number of viable $S$. aureus was constant during the first two minutes of microwave treatment with a rapid decrease (94\%) during the third minute. E. coli viability showed a sharp decline during microwave heating in the presence of iron ions. During the first minute of microwave treatment bacterial viability for $E$. coli was reduced by $99.7 \%$. Contrary to other data, E. coli disinfection denotes the strong influence of iron ions on micro-organisms.

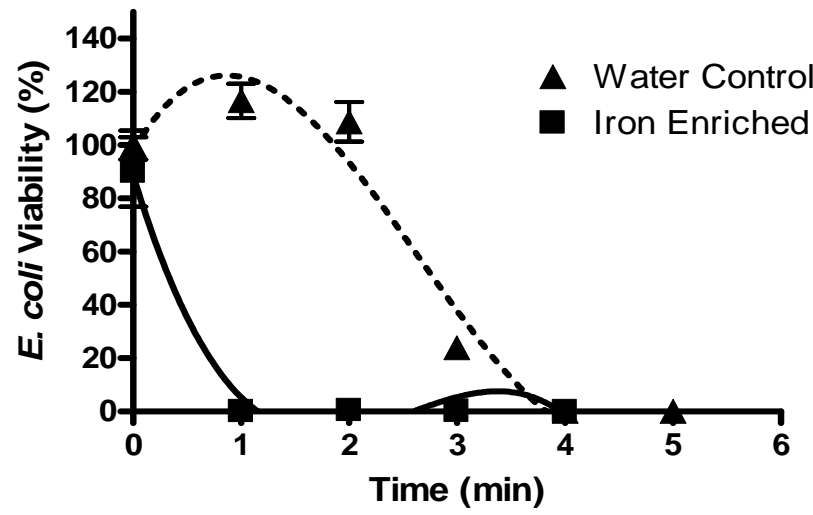

Figure 6: Effect of iron ions on microwave disinfection of E. coli. Illustrates the effect that iron ions (solid line) have on the deactivation of $E$. coli $(n=10)$ during microwave heating compared to a distilled water control (dotted line). Unlike results from E. faecalis and S. aureus, iron ions reduced the disinfection time from four minutes for the distilled water control (dotted line) to under one minute for the iron enhanced group (solid line).

For comparison, Table 2 and Figs. $4-6$, data for microwave treatment of E. faecalis, S. aureus and E. coli in distilled water (triangular points) was included from our previous paper [19]. This data showed that disinfection time in the presence of iron ions (1-3 $\mathrm{min})$ is less than in distilled water (4 - $5 \mathrm{~min})$. So, the presence of iron ions in water increased the efficiency of the microwave deactivation of bacteria.

\section{Discussion}

Results show that differences between bacterial survival and microwave time have similar "bell" shape forms for both with and excluding metal ions in most circumstances. Lower survival rates were found for $E$. faecalis, S. aureus and E. coli in the presence of metal ions under microwave heating when compared to their distilled water controls. The results suggest that metal ion's ability to enhance bacterial deactivation primarily occurs above temperatures needed for optimal growth. Microwave disinfection times for all three bacteria were also lowered in the presence of metal ions such as cobalt and iron. This shift found a reduction of bacterial viability becoming insignificantly small at the third minute of microwave heating. Experimental controls of distilled water found bacterial viability requiring $4-5 \mathrm{~min}$ of microwave irradiation for significant reduction. The rapid reduction of viable bacteria during microwave irradiation in the presence of aqueous metal ions indicates an increase of kinetic energy of the solution. Metal ions with higher kinetic energy have a greater possibility to enter into the bacteria. Initially, the addition of metal ions is seen as a source of nutrition. As the kinetic energy of the metal ion increases, there is an increase in ion penetration. Following metal ion penetration, they begin to damage the cell membranes of bacteria, disrupt cellular functions, and destroy the structure of DNA [24]. 
For preparation of mathematical model for bacterial deactivation in the presence of metal ions, we infer the assumptions of existence of two processes. Growth of bacteria by improving conditions of their reproduction on initial stage of microwave heating, and following reduction of survival bacteria by increasing of "death" factor with increasing the time of microwave irradiation.

In our previous work [19] we found that rate of change $(\mathrm{dN} / \mathrm{dT})$ of bacterial survival with water temperature $(\mathrm{T})$ is described by formula:

$$
\frac{d N}{d T}=\beta-\delta
$$

where, $\beta$ and $\delta$ - growth and decay of viable bacteria with changing water temperature on $1{ }^{\circ} \mathrm{C}$ related with "birth factor" and "death factor", respectively. $\beta$ and $\delta$ depend on temperature, and in the first approximation, we can use linear functions :

$\beta=a_{0} T+b_{0} \quad$ and $\quad \delta=a_{1} T+b_{1}$

where, $\quad a_{0}, b_{0}, a_{1}, b_{1}$ - coefficients that depend on forms of bacteria.

Assuming, the water contains metal ions with concentration $M$ we have to change the formula (1) and include the term that gives influence of metal ions on bacteria death. After this transformation formula (1) will be:

$$
\frac{d N}{d T}=\beta-\delta_{1}-\delta_{2}
$$

where, $\delta_{1}=a_{1} T+b_{1}$ - decay of bacteria number that relates with changing water temperature on $1^{\circ} \mathrm{C}$, $\delta_{2}(\mathrm{M})$ decay of bacteria number that relates with changing metal ions concentration. If metal ions concentration is permanent, we can decide that $\delta_{2}(\mathrm{M})$ is constant. Then after taking integral from (3) we will receive:

$N(T)=A_{1} T^{2}+B_{1} T+C_{1}$

where $A_{1}, B_{1}, C_{1}$ - coefficients that depend on bacteria forms, type and concentration of metal ions. Also, we can use relationship between microwave time $t$ and temperature $T$ of water [19], and find dependence between number $N$ of viable bacteria and microwave time $t$ :

$N(t)=A_{2} t^{2}+B_{2} t+C_{2}$

where $A_{2}, B_{2}, C_{2}$ - coefficients that depend on bacteria forms, type, and concentration of metal ions. Therefore, we can expect that relationship between number $N$ of viable bacteria and microwave time $t$ will be given by second order polynomial function (5).

In accordance with this theory, we carry out approximation of experimental results with polynomial function (5). Figs. $1-6$ show the results of this approximation (solid curves). For comparison with previous results, we also provided theoretical curves for water without metal ions (dotted curves). The values of the coefficients $A_{2}, B_{2}, C_{2}$ that gave the best correlation with experimental results were calculated by using the least squares method and placed into Table 3.

\begin{tabular}{|c|c|c|c|c|c|}
\hline $\begin{array}{l}\text { Metal } \\
\text { Ion }\end{array}$ & Bacteria & $A_{2}$ & $B_{2}$ & $C_{2}$ & $\begin{array}{r}\text { Coefficient of } \\
\text { correlation }\end{array}$ \\
\hline \multirow{3}{*}{ Cobalt } & E. faecalis & -24.75 & 45.19 & 95.5 & .97 \\
\hline & S. aureus & -4.825 & -14.44 & 93.4 & .91 \\
\hline & E. coli & -35.25 & 74.85 & 96.4 & .98 \\
\hline \multirow{3}{*}{ Iron } & E. faecalis & -10.42 & 15.12 & 101.3 & .97 \\
\hline & S. aureus & -23.20 & 40.4 & 95.5 & .97 \\
\hline & E. coli & 0 & -99.7 & 100 & .99 \\
\hline
\end{tabular}

Table 3: Coefficients of mathematical models (equation 5)

Table 3 shows the coefficients for the theoretical mathematical models for E. faecalis, S.aureus, and E. coli. The mathematical models show between a 0.99 and a 0.91 correlation coefficient when compared to experimental data.

Comparison of mathematical model with experimental results shows good correlation (coefficient of correlation $0.91-0.99$ ) for most results that confirm the assumptions accepted in this model. An exception is the influence of iron ions on microwave bacteria deactivation. For this influence, we recommend to use the linear model. Existence of mathematical model for microwave heating of water with metal ions allows for the determination of viable bacterial levels at predetermined times.

Acknowledgements: This work was supported by DOE (Title III) Grant \# P031B04011105 and NIH through Research Centers in Minorities Institutions (RCMI) grant \# 5 G12RR017581.

\section{References}

1. Bartram, J.; Osseiran, N.; Schlein, L.: Water for Health, Taking Charge, Geneva, 2001, pp 5-7.

2. Fukuzaki, S.: Mechanisms of actions of sodium hypochlorite in cleaning and disinfection processes. Biocontrol Sci, 2006, 11(4), 147-57.

3. Yura, T.; Nagai, H.; Mori, H.: Regulation of the heatshock response in bacteria. Annu. Rev. Microbiol., 1993, 47, 321-50.

4. Larhed, M.; Moberg, C.; Hallberg, A.: MicrowaveAccelerated Homogeneous Catalysis in Organic Chemistry. Acc. Chem. Res., 2002, 35, 717-727.

5. Lidstrom, P.; Tierney, J.; Wathey, B.; Westman, J.: Microwave assisted organic synthesis - a review. Tetrahedron, 2001, 57, 9225-9283. 
6. Datta, A. K.; Hu, W.: Quality optimization of dielectric heating processes. Food Technol., 1992, 46(12), 53-56.

7. Goldblith, S. A.; Wang, D. I., Effect of Microwaves on Escherichia coli and Bacillus subtilis. Appl. Microbiol., 1967, 15(6), 1371-1375.

8. Jeng, D. K.; Kaczmarek, K. A.; Woodworth, A. G.; Balasky, G.: Mechanism of microwave sterilization in the dry state. Appl. Environ. Microbiol., 1987, 53(9), 2133-7.

9. Kazbekov, E. N.; Vyacheslavov, L. G.: Effects of microwave irradiation on some membrane-related processes in bacteria. Gen. Physiol. Biophys., 1987, 6(1), 57-64.

10. Fujikawa, H.; Ushioda, H.; Kudo, Y., Kinetics of Escherichia coli destruction by microwave irradiation. Applied and Environmental Microbiology, 1992, 58(3), 920-4.

11. Welt, B. A.; Tong, C. H.: Effect of microwave radiation on thiamine degradation kinetics. $J$. Microwave Power Electromagnetic Energy, 1993, 28, 187-195.

12. Lechowich, R. V.; Beuchat, L. R.; Fox, K. I.; Webster, F. H.: Procedure for evaluating the effects of 2,450-megahertz microwaves upon Streptococcus faecalis and Saccharomyces cerevisiae. Appl Microbiol., 1969, 17 (1), 106-10.

13. 13. Vela, G. R.; Wu, J. F.: Mechanism of lethal action of $2,450-\mathrm{MHz}$ radiation on microorganisms. Appl. and Environ. Microbiol., 1979, 37, 550-553.

14. Rosen, C. G.: Effects of microwaves on food and related materials. Food Technol., 1972, 26, 36-40.

15. Shin, J. K.; Pyun, Y. R.: Inactivation of Lactobacillus plantarum by pulsed - microwave irradiation. J. Food Science, 1997, 62, 163-166.

16. Culkin, K. A.; Fung, D. Y. C.: Destruction of Escherichia coli and Salmonella typhimurium in microwave-cooked soups. J. Milk Food Technol., 1975, 38, 8-15.

17. Kozempel, M. F.; Annous, B. A.; Cook, R. D.; Scullen, O. J.; Whiting, R. C.: Inactivation of microorganisms with microwaves at reduced temperatures. J Food Prot., 1998, 61(5), 582-5.

18. Heddleson, R. A.; Doores, S.; Anantheswaran, R. C.: Parameters Affecting Destruction of Salmonella spp. by Microwave Heating. J. Food Sci., 1994, 59(2), 447-451.

19. Benjamin, E.; Reznik, A.; Benjamin, E.; Williams, A. L.: Mathematical Models for Conventional and Microwave Thermal Deactivation of Enterococcus faecalis, Staphylococcus aureus and Escherichia coli. Cell. Mol. Biol., 2007, 53(3), 42-48.

20. Watanabe, K.; Kakita, Y.; Kashige, N.; Miake, F.; Tsukiji, T., Effect of ionic strength on the inactivation of microorganism by microwave irradiation. Lett. Appl. Microbiol., 2000, 31, 52-56.

21. Beveridge, T. J.; Doyle, R. J.: Metal ions and bacteria. Wiley: New York, 1989, 461 p.
22. Andreini, C.; Banci, L.; Bertini, I.; Rosato, A., Zinc through the three domains of life. J Proteome Res, 2006, 5(11), 3173-8.

23. Semsey, S.; Andersson, A. M.; Krishna, S.; Jensen, M. H.; Masse, E.; Sneppen, K.: Genetic regulation of fluxes: iron homeostasis of Escherichia coli. Nucleic Acids Res., 2006, 34(17), 4960-7.

24. Bruins, M. R.; Kapil, S.; Oehme, F. W., Microbial resistance to metals in the environment. Ecotoxicol Environ Saf, 2000, 45(3), 198-207.

25. Mergeay, M.; Nies, D.; Schlegel, H. G.; Gerits, J.; Charles, P.; Van Gijsegem, F.: Alcaligenes eutrophus $\mathrm{CH} 34$ is a facultative chemolithotroph with plasmidbound resistance to heavy metals. J. Bacteriol., 1985, 162(1), 328-34.

26. Nies, D. H.: Microbial heavy-metal resistance. Appl. Microbiol. Biotechnol., 1999, 51, 730-750.

27. Nies, D. H.; Silver, S., Ion efflux systems involved in bacterial metal resistance. J. Industrial Microbiol., 1995, 14, 186-199.

28. Thurman, R. B.; Gerba, C. P.: The molecular mechanism of copper and silver ion disinfection of bacteria and viruses. Crit. Rev. Environ. Control, 1989, 18, 295-315.

29. Yahya, M. T.; Straub, T. M.; Gerba, C. P., Inactivation of coliphage MS-2 and poliovirus by copper, silver and chlorine. Can. J. Microbiol., 1992, 38, 480-485.

30. Yahya, M. T.; Straub, T. M.; Gerba, C. P.; Margolin, A. B., Inactivation of coliphage MS-2 and poliovirus in copper, galvanized and plastic domestic water pipes. Int. J. Environ. Health Res., 1991, 1, 76-86.

31. Chambers, C. W.; Proctor, M.; Kabler, P. W., Bacterial effect of low concentration of silver. $J$. Am.Water Works Assoc., 1962, 54, 208-216.

32. Butkus, M. A.; Labare, M. P.; Starke, J. A.; Moon, K.; Talbot, M.: Use of aqueous silver to enhance inactivation of coliphage MS-2 by UV disinfection. Appl Environ Microbiol., 2004, 70(5), 2848-53.

33. Abad, F. X.; Pinto, R. M.; Diez, J. M.; Bosch, A.: Disinfection of human enteric viruses in water by copper and silver in combination with low levels of chlorine. Appl Environ Microbiol., 1994, 60(7), 2377-83.

34. Landeen, L. K.; Yahya, M. T.; Gerba, C. P.: Efficacy of copper and silver ions and reduced levels of free chlorine in inactivation of Legionella pneumophila. Appl Environ Microbiol., 1989, 55(12), 3045-50.

35. Short, B. R. D.; Vargas, M. A.; Thomas, J. C.; O'Hanlon, S.; Enright, M. C.: In vitro activity of a novel compound, the metal ion chelating agent $\mathrm{AQ}^{+}$, against clinical isolates of Staphylococcus aureus. Journal of Antimicrobial Chemotherapy, 2006, 57(1), 104-109.

36. Radab-Depre, N. J.: Water disinfection with hydrogen peroxide-ascorbic acid-copper (II) system. Appl. Environ. Microbiol., 1982, 44, 555-560.

37. Oganesov, V. E.: Device for water deactivation by using silver ions, 1998. 
38. Myers, C. R.; Nealson, K. H.; Saffarini, D.: Bacterial Manganese Reduction and Growth with Manganese Oxide as the Sole Electron Acceptor Science, 1988, 240(4857), 1319 - 1321.

39. Nealson, K. H.; Saffarini, D.: Iron and Manganese in anaerobic respiration: environmental significance, physiology, and regulation. Annu. Rev. Microbiol. 1994, 48, 311-343.

40. Calomiris, J. J.; Armstrong, J. L.; Seidler, R. J.: Association of metal tolerance with multiple antibiotic resistances of bacteria isolated from drinking water. Appl Environ Microbiol, 1984, 47(6), 1238-42.

41. Nakahara, H.; T., I.; Sarai, Y.; Kondo, I., Distribution of resistance to metals and antibiotics of Staphylococcal strains in Japan. Zentralbl. Bakteriol. Mikrobiol., 1977, 237, 470-476.

42. Nakahara, H.; T., I.; Sarai, Y.; Kondo, I.; Kozulue, H.; Silver, S.: Linkage of mercury, cadmium, and arsenate and drug resistance in clinical isolates of Pseudomonas aeruginosa. Appl. Environ. Microbiol., 1977, 33, 975-976. 